\title{
Analgesic and Anti-Inflammatory activities of Rothmannia Longiflora Salisb In Mice And Rats
}

\author{
*1 Danjuma Mallam, ${ }^{2}$ Joseph A,Anuka, ${ }^{2}$ Abdulkadir U,Zezi, ${ }^{2}$ Mohammed \\ G,Magaji, ${ }^{1}$ Ben A,Chindo, ${ }^{2}$ Mohammed B,Sani, \\ ${ }^{I}$ Department of Pharmacology and Toxicology, Kaduna State University, Kaduna, Nigeria \\ ${ }^{2}$ Department of Pharmacology and Therapeutics, Ahmadu Bello University, Zaria, Nigeria
}

\begin{abstract}
In this study, the analgesic and anti-inflammatory activities of the methanolic leaf extract of Rothmannialongiflora were investigated. The methanolic leaf extract of the plant at the doses of 250, 500, and $1000 \mathrm{mg} / \mathrm{kg}$ orally was evaluated for analgesic activity using acetic acid-induced writhing test, hot plate test and formalin test. The anti-inflammatory potential of the extract was evaluated using carrageenan-induced paw oedema test in rats. The methanolic leaf extract exhibited significant dose dependent analgesic and antiinflammatory effects comparable to piroxicam $(20 \mathrm{mg} / \mathrm{kg}$ body weight orally), which is a standard analgesic and anti-inflammatory drug. The preliminary phytochemical screening of the methanolic leaf extract of Rothmannialongiflora revealed the presence of flavonoids, tannins, saponins, glycosides, steroids/terpanoids, and carbohydrates. The oral median lethal dose $\left(\mathrm{LD}_{50}\right)$ of the extract in mice and rats were found to be greater than $5000 \mathrm{mg} / \mathrm{kg}$, suggesting that the methanolic leaf extract of Rothmannialongiflora is non-toxic. The present findings suggest that the methanolic leaf extract of the plant possesses analgesic and anti-inflammatory activities, and supports the ethno medical claims of the use of the plant in the management of pain and inflammatory conditions.
\end{abstract}

Keywords:Acetic acid, anti-inflammatory, formalin test, medicinal plants, RothmannialongifloraSalisb

\section{INTRODUCTION}

Medicinal herbs have been used as a form of therapy for the relief of pain throughout history[1]. The treatment of rheumatic disorder is an area in which the practitioners of traditional medicine enjoy patronage and success[2]. Scientific findings from research into substances used in herbal medicine practices led to discovery of relevant plants with useful chemical constituents that can be used in treatment of various diseases [3]. Since most important analgesic prototypes (for salicylic acid and morphine) were originally derived from the plant sources, the study of plant species traditionally used as pain killers is still considered as a fruitful research strategy in the search for new analgesic and anti-inflammatory drugs.Medicinal plants with anti-inflammatory activity are considerably employed in the traditional treatment of disorders of inflammation. The inflammatory responses involve a complex array of enzyme activation, mediator released fluid extravasations, cell migration, tissue breakdown and repair [4], which are aimed at host defence and usually activated in most disease conditions.

RothmannialongifloraSalisb (Family: Rubiaceae) is found in Gambia, Sudan, Kenya, Tanzania, Angola and is also found in Nigeria, Ghana, Sierra Leone, Democratic Republic of Congo, Ivory Coast, Uganda, Liberia and Cameroon.In Nigeria, the common vernacular names of Rothmannialongiflora include: 'Katambiri' (hausa),'Igbo:’Uli,Alankitauku,mbembe(Ogwashi)'Yoruba: 'Edo-pata,Kerebuje(Ononchie),

segoikorun(Millson).Rothmannialongiflora is considered to have febrifugal and analgesic properties, and a decoction of the leaves, twigs, bark and roots is applied internally or externally as lotions, washes and baths[5]. In Nigeria the roots are used to treat bowel complaints[6]. To the best of our knowledge, there is no information in the literature on the analgesic and anti-inflammatory potentials of the plant. This study therefore aimed at evaluating the analgesic and anti-inflammatory properties of the methanol leaf extract of Rothmannialongiflora in laboratory animals.

II.

\section{MATERIALS AND METHODS}

\subsection{Preparation of the Extract}

The leaves of Rothmannialongiflorasalisbwere collected in Gargai, Bagauda Road, Kano, Kano State, Nigeria, in October 2010 by Malam Umar. S. Gallah and was identified by Mallam Musa Mohammed of the Herbarium Section of Biological Science Department of Ahmadu Bello University (ABU), Zaria by comparing with existing specimen (Voucher specimen number: 2877).The leaves were air dried under shade (until constant weight was obtained) and then size-reduced into coarse powder with a pestle and mortar. The powdered leaves 
(500g) were extracted with 2.5Litres of $100 \%$ Methanol for 72 hours using soxhlet extraction apparatus. The solvent was evaporated (at reduced pressure) to give an average yield of $29.47 \% \mathrm{w} / \mathrm{w}$.

The extract was then stored in the freezer at temperature of $4{ }^{\mathrm{oC}}-5^{\mathrm{oC}}$ until needed for the work.

\subsection{Experimental Animals}

Wistar rats (150-250g) and Swiss Albino mice (18-30g) of both sexes were obtained from Animal House, Department of Pharmacology and Therapeutics, A.B.U-Zaria and National Research Institute for Chemical Technology (NARICT), Basawa, Zaria, Kaduna State.

The rats and mice were maintained in a well ventilated room in the laboratory animal house under standard laboratory conditions of temperature $\left(25 \pm 2^{0 \mathrm{C}}\right)$ and light (approximately $12 / 12 \mathrm{~h}$ light/dark cycle). They were fed on Vital Grower feeds (Vital feeds, Jos-Plateau State) and watered adlibitum. All experimentals protocols were approved by the University Animal Ethics Committee.

\subsection{Drugs/Chemicals}

Glacialaceticacidsolution(Searle Essex, EnglandCarrageenan solution (Sigma-Aldrich LaborchemikaleinGmBH Germany). Cap Piroxicam 20mg (Hovid Pharmaceutical Company, Malaysia).

\subsection{Preliminary Phytochemical Analysis}

Rothmannialongiflora was subjected to preliminary phytochemical screening using standard protocols[7].

\subsection{Lethal Dose $\left(\mathrm{LD}_{50}\right)$ Determination in Rats and Mice}

$\mathrm{LD}_{50}$ determinations were conducted using Lorke's method[8] for intraperitoneal and oral routes in mice and rats. This method was carried out in two phases. In the initial phase, 3 groups each containing three animals were treated with methanolic leaf extract of the plant at doses of 10,100 and $1000 \mathrm{mg} / \mathrm{kg}$ body weight i.p/orally and were observed for signs of toxicity and death for 24 hours. In the second phase, 4 groups each containing one animal were administered with four more specific doses of the extract $1200 \mathrm{mg}, 1600 \mathrm{mg}$, $2900 \mathrm{mg}$, and $5000 \mathrm{mg} / \mathrm{kg}$ body weight based on the result of phase one (initial phase). The $\mathrm{LD}_{50}$ value was determined by calculating the geometric mean of the highest non-lethal dose (for which the animal survived) and the lowest dose (for which the animal died).

\subsection{Acetic Acid Induced Writhing Test in Mice}

This was conducted using the method described by Koster[9]. Swiss albino mice were divided into 5 groups each containing 6 mice. Groups 1 was given $250 \mathrm{mg} / \mathrm{kg}$, group 2 was given $500 \mathrm{mg} / \mathrm{kg}$, group 3 was given $1000 \mathrm{mg} / \mathrm{kg}$ of the extract orally; the fourth $\left(4^{\text {th }}\right)$ group which served as the control was given normal saline equivalent to the vehicle given with the extract orally. The $5^{\text {th }}$ group was given $20 \mathrm{mg}$ Piroxicam per $\mathrm{kg}$ body weight orally as positive control. After 60 minutes, mice in all the groups were treated with $0.6 \%$ acetic acid $(10 \mathrm{ml}$ per $\mathrm{kg}$ body weight i.p). Five minutes after the acetic acid administration, the mice were placed in individual cages and the numbers of abdominal contractions were counted for each mouse for a period of 10 mins after 5 minutes latency period using a tally counter.

\subsection{Hot Plate Test in Mice}

The method described by (Lanhers[10] and modified by Mohamed and Ojewole[11] was employed. A $600 \mathrm{ml}$ test beaker was placed on a regulated thermostat hot plate at $55^{\circ} \mathrm{C} \pm 1{ }^{\circ} \mathrm{C}$.Each mouse was placed in the beaker (on the hot plate) and the response to electrical heat-induced nociceptive pain stimulus obtained. Licking of the paws or jumping out of the beaker was taken as indicator of the animals' response to heat-induced nociceptive pain stimulus. The time taken for each mouse to lick its paws or jump out of the beaker was noted (reaction time). Each mouse served as its own control. Before treatment, its reaction time was taken thrice at 1 hour interval and the mean represents reaction time before treatment of the mouse. The mean reaction time of the groups was pooled to obtain the final control mean reaction time $(\mathrm{Tb})$. The mice were divided into 5 groups each consisting of 6 mice. Groups 1,2 and 3 received $250 \mathrm{mg} / \mathrm{kg}, 500 \mathrm{mg} / \mathrm{kg}$, and $1000 \mathrm{mg} / \mathrm{kg}$ of the extract orally, respectively while group 4 served as the control and received normal saline $(10 \mathrm{ml} / \mathrm{kg})$. The fifth group received the standard drug $(5 \mathrm{mg} / \mathrm{kg}$ morphine sulphate), subcutaneously.One hour after treatment; with the extract and thirty minutes after morphine, the reaction time of each mouse was again taken but only once.

\subsection{Formalin Test in Rats}

The method described by Dubuisson and Dennis [12] and modified by Tjolsen was used. Adult Wistar rats were divided into 5 groups each containing six rats. Groups 1,2 and 3 , and 4 received $250 \mathrm{mg} / \mathrm{kg}$, $500 \mathrm{mg} / \mathrm{kg}$, and $1000 \mathrm{mg} / \mathrm{kg}$ of the extract orally respectively; the 4th group served as negative control and was given normal saline equivalent to vehicle given with the extract. The $5^{\text {th }}$ group was given $5 \mathrm{mg}$ Morphine per $\mathrm{kg}$ 
body weight subcutaneously. One hour after the treatment, 50microlitre $(0.05 \mathrm{ml})$ of a freshly prepared $2.5 \%$ solution of formalin was injected subcutaneously under the planter surface of the left hind paw of each rat. They were placed in an observation chamber and monitored for one hour. Pain responses were scored according to a pain scale. The severity of pain response was recorded for each rat based on the following scale:

$0=$ rat walked or stood firmly on the injected paw

$1=$ the injected paw was favoured or partially elevated

$2=$ the injected paw was clearly lifted off the floor

$3=$ the rat licked, chewed or shook the injected paw.

Each animal was placed in such a way as to ensure un-obstructed view of the injected paw. Anti-nociceptive effect was determined in two phases;

The early phase (phase1) was recorded in the first 5 minutes while the late phase (phase 2) was recorded during the last 45 minutes with a 10 minutes lag period in between both phases.

\subsection{Carrageenan-induced paw Oedema}

The method described by Winter [13] was used. Healthy Wistar rats of either sex were fasted for 12 hours and deprived of water and were grouped into 5 with each containing 6 rats. Groups 1, 2, 3 received $250 \mathrm{mg} / \mathrm{kg}, 5000 \mathrm{mg} / \mathrm{kg}$, and $1000 \mathrm{mg} / \mathrm{kg}$ of the extract per $\mathrm{kg}$ body weight by oral administration respectively. The $4^{\text {th }}$ group served as control and was given normal saline, while the $5^{\text {th }}$ group was given Piroxicam $(20 \mathrm{mg} / \mathrm{kg})$ body weight orally. One hour later, $0.1 \mathrm{ml}$ of freshly prepared Carrageenan suspension $(1 \% \mathrm{w} / \mathrm{v}$ in $0.9 \%$ normal saline) was injected into the sub planter region of the left hind paw of each rat. The paw diameter was measured with the aid of a verniercalliper at $0,1,2,3,4,5$ hours, after the injection of Carrageenan.

\subsection{Data Analysis}

The data were analysed and expressed as Means \pm SEM (Standard Error of Mean)

Difference between the control and treated groups were analysed using one way Analysis of variance followed by post hoc dunnet t-test.

$\mathrm{P}<0.05$ were considered to be statistically significant.

\section{III. RESULTS}

\subsection{Preliminary Phytochemical Screening}

The preliminary phytochemical screening revealed the presence of cardiac glycoside, steroids/terpenoids, tannins, saponins, flavonoids, carbohydrate, and alkaloids but cyanogenic glycoside was found to be absent (TABLE 1).

Table 1.Preliminary phytochemical screening result of methanolic leaf extract of $R$. longiflora

\begin{tabular}{cc}
\cline { 2 - 2 } Constituents & Remarks \\
\hline
\end{tabular}

$\begin{array}{lc}\text { Cardiac glycoside } & + \\ \text { Steroids/terpenoids } & + \\ \text { Tannins } & + \\ \text { Saponins } & + \\ \text { Flavonoids } & + \\ \text { Carbohydrate } & + \\ \text { Alkaloids } & + \\ \text { Cyanogenic glycoside } & -\end{array}$

$$
\begin{gathered}
+=\text { Present } \\
++=\text { Highly present } \\
-=\text { Absent }
\end{gathered}
$$

\subsection{Lethal dose $\left(\mathrm{LD}_{50}\right)$ Test}

The intraperitoneal and oral lethal dose values $\left(\mathrm{LD}_{50}\right)$ of the methanolic leaf extract of Rothmannialongiflora in both mice and rats were found to be greater than $5000 \mathrm{mg} / \mathrm{kg}$ body weight. There were no behavioural signs of toxicity exhibited by any mouse or rat that received the various doses of the extract.

\subsection{Effect of the Extract on Acetic Acid-induced Writhing in Mice}


The extract significantly $(\mathrm{P}<0.05)$ inhibited the acetic acid-induced abdominal writhes in mice, dose dependently. The highest inhibition of abdominal constriction observed at $1000 \mathrm{mg} / \mathrm{kg}$ was greater than that of Piroxicam, the standard non-steroidal anti-inflammatory drug used at a dose of $20 \mathrm{mg} / \mathrm{kg}$ body weight (fig 1).

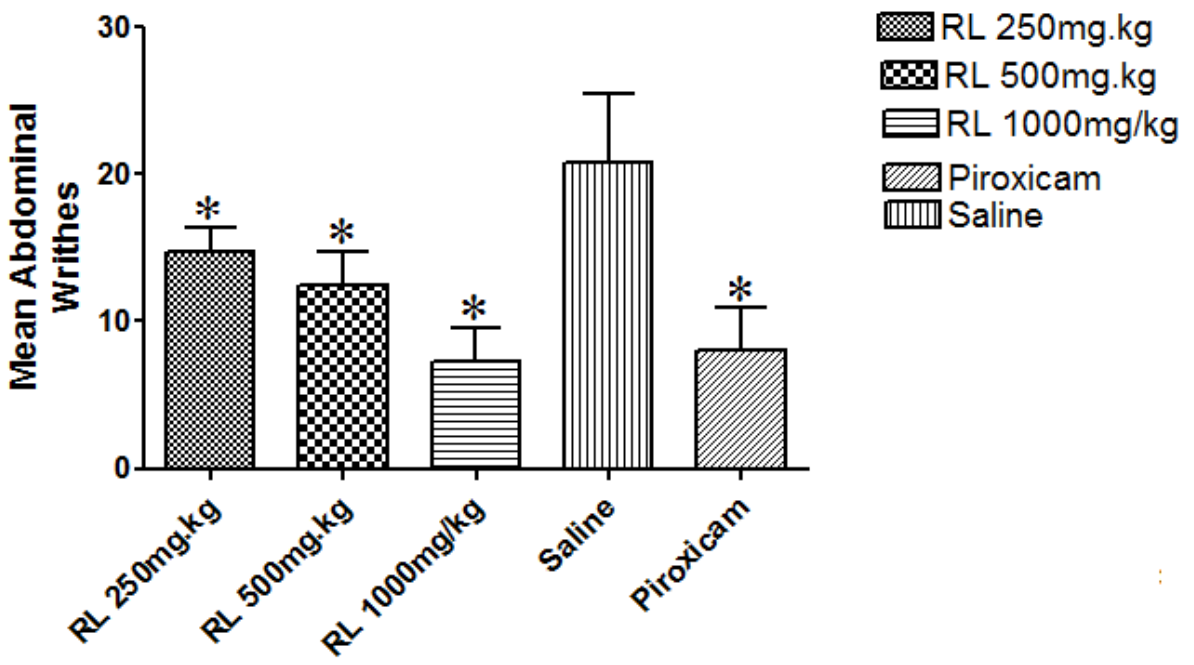

Figure 1: Effect of the extract on abdominal constrictions induced by acetic acid in mice.

$* \mathrm{P}<0.05$ shows significant statistical difference compared to control (Normal saline); $\mathrm{n}=6$. Each value is expressed as Mean \pm SEM.

$\mathbf{R} \mathbf{L}=$ Rothmannialongiflora extract.

\subsection{Effect of theExtract onthermally induced Pain Stimulus in Mice.}

The methanolic leaf extract of R.longiflora significantly $(\mathrm{P}<0.05)$ and dose-dependently protected the mice against thermally induced pain stimulus in mice. The $500 \mathrm{mg}$ dose of the R.longiflora extract offered more than $100 \%$ protection; $1000 \mathrm{mg}$ offered more than $200 \%$ and the standard drug morphine sulphate offered more than $300 \%$ protection against thermally induced pain stimulus in mice

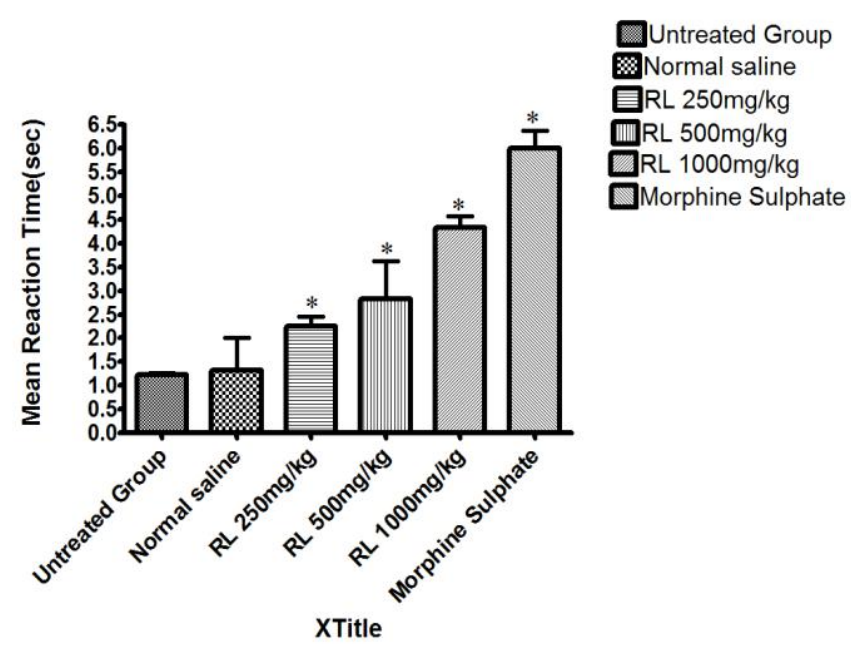

Figure 2: Effect of the extract on thermally induced pain stimulus in mice (Hot plate method)

* $\mathrm{P}<0.05$ shows significant statistical difference compared with the treated control (normal saline); $\mathrm{n}=6$. Each value is expressed as Mean \pm SEM.

3.5 Formalin Test in Rats.

$\mathbf{R L}=$ Rothmannialongiflora extract

There was no significant inhibition of both the neurogenic pain (early phase) and inflammatory pain (late phase) at $250 \mathrm{mg} / \mathrm{kg}$ dose of the extract.

But the significant $(\mathrm{P}<0.05)$ inhibition of both the neurogenic (early phase) and inflammatory (late phase) pain was dose dependent at $500 \mathrm{mg} / \mathrm{kg}$ and $1000 \mathrm{mg} / \mathrm{kg}$ with highest inhibition at $1000 \mathrm{mg} / \mathrm{kg}$. The significant $(\mathrm{P}<0.05)$ inhibition of the standard drug morphine sulphate at late phase doubled that of the early phase. 


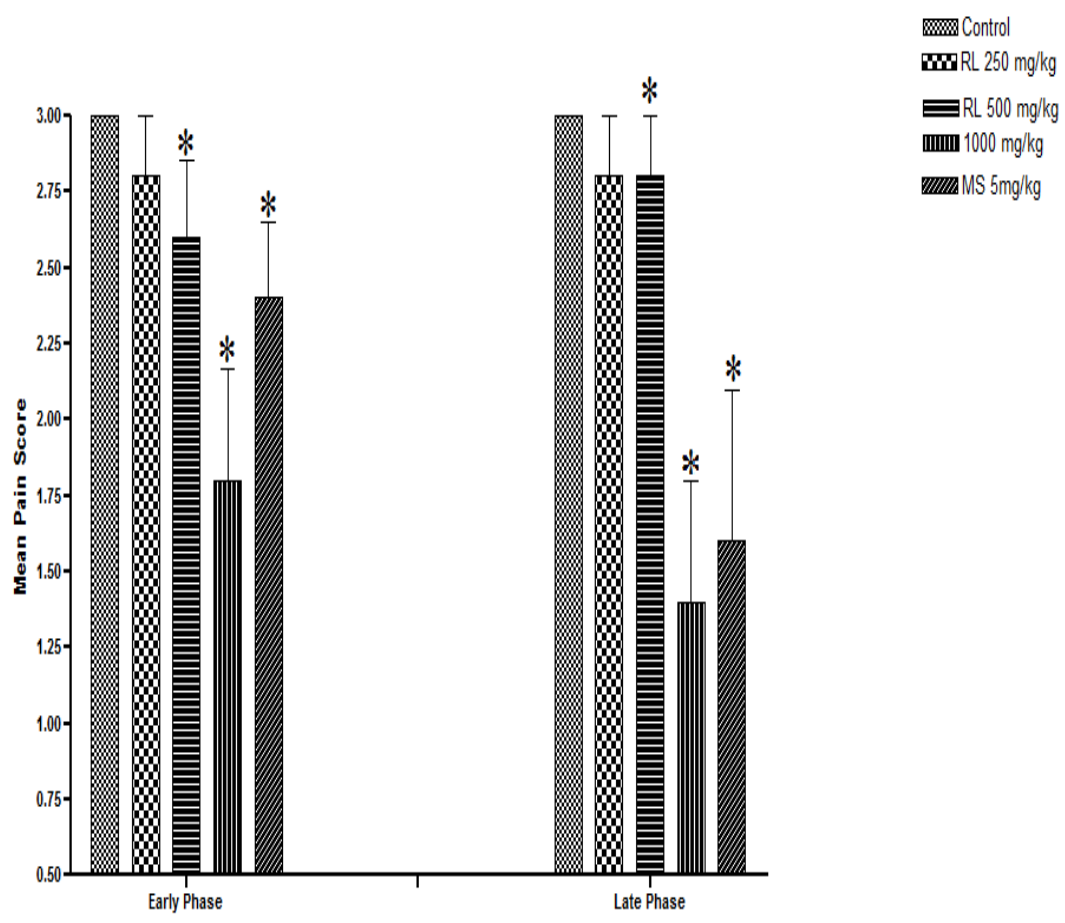

Figure 3: Effects of the extract on formalin test in rats. $* \mathrm{P}<0.05$ significant statistical difference compared with the treated control (normal saline); $n=5$. Each value is expressed as Mean \pm SEM.

MS = Morphine Sulphate

$\mathbf{R} \mathbf{L}=$ Rothmannialongiflora extract

\subsection{Carrageenan-induced paw Oedema}

The methanolic leaf extract of R.longiflora significantly $(\mathrm{P}<0.05)$ inhibited the paw oedema at doses of; $250 \mathrm{mg} / \mathrm{kg} ; 500 \mathrm{mg} / \mathrm{kg}$ and $1000 \mathrm{mg} / \mathrm{kg}$ (table 2 ) showed a dose-dependent inhibition).

The percentage anti-inflammatory effects at the peak of Carrageenan-induced oedema at the 3rd hour were: $39.39 \% ; 51.52 \%$; $63.63 \%$ at respective doses of: $250 \mathrm{mg} / \mathrm{kg} ; 500 \mathrm{mg} / \mathrm{kg} ; 1000 \mathrm{mg} / \mathrm{kg}$ compared to $69.70 \%$ for Piroxicam $20 \mathrm{mg} / \mathrm{kg}$ body weight(standard anti-inflammatory agent (TABLE 2).

Table 2: The effect of the extract on carrageenan-induced paws oedema in rats Treatment (Dose)

$\mathrm{Mg} / \mathrm{kg} \quad$ Mean Paw Diameter (cm)

\begin{tabular}{cccccc}
$0 \mathrm{hr}$ & $1 \mathrm{hr}$ & $2 \mathrm{hr}$ & $3 \mathrm{hr}$ & $4 \mathrm{hr}$ & $5 \mathrm{hr}$ \\
\hline
\end{tabular}

Normal

Saline

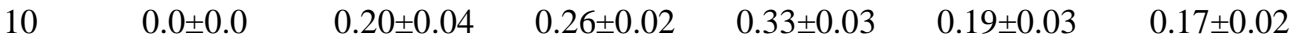

Extract

250

$0.0 \pm 0.0 \quad 0.19 \pm 0.03$

$0.16 \pm 0.03$

$0.20 \pm 0.03^{\mathbf{a}}$

$0.09 \pm 0.02^{\mathrm{a}}$

$0.07 \pm 0.03^{\mathrm{a}}$

Extract

500

(5.00)

(38.46)

(39.39)

(52.63)

(58.82)

Extract

1000

$0.0 \pm 0.0$

$0.15 \pm 0.02$

$0.13 \pm 0.02^{\text {b }}$

$0.16 \pm 0.02^{b}$

$0.05 \pm 0.02^{c}$

$0.05 \pm 0.01^{\mathrm{c}}$

(25.00)

(50.00)

(51.52)

(73.68)

(70.59)

Piroxicam
20

$20 \quad 0.0 \pm 0.0 \quad 0.10 \pm 0.02^{\mathrm{b}} \quad 0.08 \pm 0.03^{\mathrm{c}} \quad 0.10 \pm 0.02^{\mathrm{c}} \quad 0.05 \pm 0.01^{\mathrm{c}} \quad 0.03 \pm 0.01^{\mathrm{c}}$

$0.12 \pm 0.01^{\mathrm{b}}$
$(40.00)$

$0.10 \pm 0.02^{\mathrm{c}}$
$(61.54)$

$0.12 \pm 0.01^{\mathrm{c}}$

$0.04 \pm 0.02^{\mathrm{c}} \quad 0.04 \pm 0.0^{\mathrm{c}}$

(63.63)

(78.95)

(76.47) 
$\begin{array}{llll}(50.00) & (69.23) & (69.70) & (73.68)\end{array}$

${ }^{\mathrm{a}} \mathrm{P}<0.05 ;{ }^{b} \mathrm{P}<0.01 ;{ }^{\mathrm{c}} \mathrm{P}<0.001$ compared to control (Normal saline), $\mathrm{n}=5$. Each value is expressed as mean \pm SEM. Figures in parentheses represent percentage anti-inflammatory activity

\section{DISCUSSION}

The oral and intraperitoneal values of $\mathrm{LD}_{50}$ were found to be greater than $5000 \mathrm{mg} / \mathrm{kg}$ body weight in both rats and mice, suggesting that the extract is non-toxic at the graded doses $(250,500$ and $1000 \mathrm{mg} / \mathrm{kg})$ orally and intraperitoneally according to Lorke's 1983 lethal dose determination. The inhibition of the acetic acid induced writhing by the extract is an indication of its analgesic potential. The abdominal constrictions response induced by acetic acid is a sensitive procedure to evaluate peripherally acting analgesics [14]. Acetic acid causes pain generally by liberating endogenous substances such as serotonin, histamine, prostaglandins, bradykinins and substances which stimulate nerve endings. Therefore, the analgesic activity of the extract may be peripherally mediated via the inhibition of synthesis and releases of prostaglandins and other endogenous compounds. Pain

induced by thermal stimulus of the hot plate is specific for centrally mediated nociception. The ability of the extract to prolong the reaction latency to pain thermally induced in mice by the hot plate further supports its central analgesic activity.

The formalin test showed a distinctive biophasic responses termed early and late phases. Drugs that act primarily on the CNS inhibit both phases equally while peripherally acting drugs inhibit the late phase[15, 16]. The first phase is probably a direct result of stimulation of nociceptors in the paw. Stimulation of the opioid receptors has also been suggested as a possible mechanism of action against neurogenic pain [17]. This phase therefore reflects centrally mediated pain while the late phase is due to inflammation with release of serotonin, histamine, bradykinin and prostaglandins and atleast to some degree, the sensitisation of central nociceptive neurons. The suppression of both phases as observed in the highest dose tested $(1000 \mathrm{mg} / \mathrm{kg})$ in this study suggests the presence of both central and peripheral effects. However, the extract has greater inhibitory effect on the peripheral mechanism (inflammatory pain) which showed $53.33 \%$ protection at the late phase against the neurogenic pain (central mechanism) $40.0 \%$ at the early phase.

The injection of $1 \%$ Carrageenan suspension in the paws of the negative control treated rat with Normal Saline produced a local oedema reaching its maximumat the third $\left(3^{\text {rd }}\right)$ hour.

The probable mechanism of action of carragenan-induced inflammation is bi-phasic. The first phase is attributed to the release of histamine, serotonin, and kinins in the first hour; while the second phase is attributed to the release of prostaglandins and lysosome enzymes in 2 to 3 hours [18]. The methanolic leaf extract of the plant significantly inhibited the Carrageenan-induced inflammation in a dose dependent manner and this effect is comparable to that of piroxicam. Therefore, the mechanism of action of the extract may be by inhibition of histamine, serotonin or prostaglandins synthesis. Most anti-inflammatory and analgesic drugs possess antipyretic activity. In general, non-steroidal anti-inflammatory drugs produce their antipyretic action through the inhibition of prostaglandin synthetase in the hypothalamus [19]. The analgesic and anti-inflammatory activities of methanolic leaf extract may be due to the presence of alkaloids, tannins, saponins and flavonoids which have been previously reported to poessess analgesic and anti-inflammatory potential.

\section{CONCLUSION}

In conclusion, the present findings provide some pharmacological rationale for the use of the leaf of $\mathrm{R}$. longiflora in traditional medicine. However, further investigation is required to isolate the active constituents responsible for these activities and to establish the exact mechanism (s) of analgesic and anti-inflammatory activities of the methanolic leaf extract of the plant.

\section{ACKNOWLEDGMENT}

We wish to thank Mal. Yau Mohammed of the Animal House Unit,Ahmadu Bello University, Zaria, and Mr. John Kono of Pharmacology Laboratory Ahmadu Bello University, for their technical supports.

\section{CONFLIC OF INTEREST}

There is no conflict of interest in this study.

\section{REFERENCES}

[1] Almeida, R. N., Navarro, D. S and Barbosa, Filho. J. M. Plants with central analgesic activity.Phytomedicine.2001; 8: 310-322.

[2] Akah. P. A .Nwambie, A.I. Evaluation of Nigerian traditional medicines: plants used for rheumatic disorder. Journal of Ethnopharmacology.1994; 42: 179-182. 
[3] Amos, S., Kolawole, E., Akah, P., Wambebe, C.andGamaniel, K.Behavioural effects of the aqueous extract of Guierasenegalensis in mice and rats.Phytomedicine. 2001; 8(5):356-361

[4] Tjolsen, A., Berge, O., Huskaar, S., Rosland, J.H. and Hole, K. The formalin test: an evaluation of the method. Pain.1992; 52:5-17.

[5] Irvine F.R. Woody Plants of Ghana $1^{\text {st }}$ ed. Oxford University Press London. 1961, pp 487

[6] Dalziel, J.M.The useful plants of west tropical Africa. Crown Agents for Overseas Governments Administrations, London, Unite d Kingdom.1937, Pp 612

[7] Vane J. R., and Bolting R.M. New insight into the mode of action of anti-inflammatory drugs, inflammatory research 1995; 44 (1): 1-10.

[8] Lorke D.A. A new Approach to practical Acute Toxicity testing. Archives of Toxicity.1983; 54:275 - 287

[9] Koster, R., Anderson, M. and De Beer, E.J. Acetic acid for analgesic screening, Federal Proceedings. 1959; $18,412-417$.

[10] Lanhers, M.C. Fleurentin, J. Mortar, F. Vinche, A and Younos, C.Anti-inflammatory and Analgesic effects of an aqueous extract of HarpagophytumProcumbens. Planta Medica.1992; 58:117-123

[11] Mohamed I.M. and Ojewole, J.A.O. Analgesic, Antinflammatory and Antidiabetic Properties ofHarpagophytum Procumbent DC (Pedaliaceae) Secondary Root Aqueous Extract. Phytotherapy Research. 2004; 18:982-989

[12] Dubuisson, D and Dennis, S.R. The formalin: A quantitative study of the analgesic effects of morphine, and meperidine and brain stem stimulation in rats and cats. Pains.1977;4:161-174

[13] Winter, C.A., Riselay, E.A. and Nuss, G.W. Carrageenan induced oedema in the limb paw of the rats as assay for anti-inflammatory drugs. Proc.soc. Exp. Bio.Med.1962;111:544-547

[14] Gene, R.M., Segura,L., Adzet T., Marin,E.andInglesias,J. Heterothecainuloides: anti-inflammatory and analgesic effects. Journal of Ethnopharmacology.1998; 60:157-162

[15] Shibata, M., Ohnkubo, T., Takahashi, H. and Inoki, R. Modified formalin test: characteristic biphasic pain response. Pain,1989; 38:347-352

[16] Chan,Y.F., Tsai,H.Y., Wu, T.S. Anti-inflammatory and analgesic activity ofextracts from the roots of Angelica Pubescens. Planta Medica,1995; 61:2-8.

[17] Gaertner, M., Muller, L., Roos, J.F, Cani, G, Santos,A.R., Niero., Calixto, J.B, Yunes,R.A., DelleMonache, F. and CechinelFilho, V. Analgesic triterpenes from Sebastianiaschottiana root. Phytomedicine, 1999; 6:41-44.

[18] Brook,P.M. and Day, R.O. Non- steroidal anti-inflammatory drugs difference and similarities. New England Journal of Medicine. 1991; 324:1716-1725

[19] Hayare S.W., Chandra,S., Tandan, S.K., Sarma,J., Lai,J., and Telang,A.G. Analgesic and antipyretic activities of Dalbergiasisso leaves., Indian Journal of Pharmacology.2000; 32:357-360 